\title{
Pengembangan Project Based Learning Berbasis Kearifan Lokal Berorientasi pada Kemampuan Berpikir Kreatif dan Kemandirian Belajar
}

\author{
Iik Nurhikmayati ${ }^{*}$ dan Aep Sunendar ${ }^{2}$ \\ Program Studi Pendidikan Matematika, Universitas Majalengka \\ Jl. K.H Abdul Halim No. 103, Majalengka,Jawa Barat, Indonesia \\ 1*ik.nurhikmayati@gmail.com \\ Program Studi Pendidikan Matematika, Universitas Siliwangi \\ Jl. Siliwangi No 24 Kel. Kahuripan Kec. Tawang Kota Tasikmalaya, Indonesia \\ 2aepfromciamis@gmail.com
}

Artikel diterima: 24-10-2019, direvisi: 28-01-2020, diterbitkan: 31-01-2020

\begin{abstract}
Abstrak
Penurunan minat peserta didik terhadap keanekaragaman budaya menjadi semakin besar, terutama di kalangan remaja. Penyebabnya adalah globalisasi yang dengan cepat menggeser nilai-nilai kebudayaan bangsa. Pengembangan model pembelajaran Project Based Learning ( $\mathrm{PjBL}$ ) berbasis kearifan lokal (KA) merupakan upaya meningkatkan minat peserta didik pada pelestarian budaya melalui pembelajaran. Tujuan penelitian adalah untuk menghasilkan model pembelajaran matematika PjBL-KA berorientasi pada peningkatan kemampuan berpikir kreatif dan kemandirian belajar yang ditinjau dari aspek kevalidan, kepraktisan dan keefektifan. Sampel penelitian yaitu mahasiswa semester II Program Studi Pendidikan Matematika Universitas Majalengka 2018/2019. Penelitian pengembangan (R\&D) yang mengadopsi model 4D yaitu Define, Design, Development dan Dissemination. Hasil penelitian adalah Model PjBL-KA telah memenuhi kriteria valid, praktis, dan efektif terhadap kemampuan berpikir kreatif, serta terdapat pengaruh positif yang signifikan antara kemandirian belajar dan kemampuan berpikir kreatif matematis.

Kata Kunci: Pengembangan Model Pembelajaran, Project Based Learning, Kearifan Lokal, Kemampuan Berpikir Kreatif, Kemandirian Belajar.
\end{abstract}

\section{Development of Project-Based Learning Based on Lokal Wisdom Model- Oriented in Creative Thinking Ability and Learning Independence}

\begin{abstract}
Decreased student interest in cultural diversity is becoming increasingly large, especially among teenagers. The Reason is globalization which is rapidly shifting the nation's cultural values. The development of Project-Based Learning models (PjBL) based on Lokal Wisdom (LW) is one of the efforts to increase students' interest in cultural preservation through learning. This study aims to produce a PjBL-LW mathematical learning model that is oriented towards improving creative thinking abilities and self-regulated learning in terms of validity, practicality, and effectiveness. This research was conducted on the second-semester students of the Mathematics Education Study Program Majalengka University Academic Year 2018/2019. This research is a Research and Development (R\&D) model, namely Determine, Design, Development, and Dissemination. The results showed that: (1) The PjBL-LW model developed has fulfilled valid criteria, practice and effective for creative thinking abilities, and (2) There is a significant positive effect between self-regulated learning and mathematical creative thinking ability.

Keyword: Development of Learning Models, Project Based Learning, Lokal Wisdom, Creative Thinking Ability, self-regulated learning.
\end{abstract}

Mosharafa: Jumal Pendidikan Matematika

Volume 9, Nomor 1, Januari 2020

Copyright $\odot 2020$ Mosharafa: Jurnal Pendidikan Matematika 


\section{Pendahuluan}

Budaya lokal merupakan salah satu identitas suatu bangsa yang dapat masyarakat setempat. Teknologi dan informasi saat ini sangat kuat dalam memberikan pengaruh buruk terhadap budaya lokal. Perkembangan IImu Pengetahuan dan Teknologi menyebabkan degradasi budaya (Mungmachon, 2012) yang menyebabkan semakin memudarnya budaya asli dan kurangnya dukungan dan semangat masyarakat untuk mempertahankan dan melestarikan teknologi dan pengetahuan lokal (Suastra, 2005; Wagiran, 2011). Salah satu buktinya adalah penurunan minat peserta didik terhadap keanekaragaman budaya setempat yang semakin besar. (Annafi \& Agustina, 2018) menyatakan bahwa materi yang selama ini diajarkan tidak sesuai dengan potensi daerah dan konteks sosial masyarakat. Oleh karena itu, budaya lokal yang menjadi identitas bangsa perlahanlahan akan hilang.

Pembelajaran matematika berbasis kearifan lokal adalah wujud nyata pendidikan karakter yang dapat dilakukan pendidik dalam upaya melestarikan budaya lokal. Dalam proses pembelajarannya peserta didik dapat mengembangkan potensi diri dengan mengintegrasikan potensi kearifan lokal, sehingga ilmu pengetahuan yang diperoleh dapat berguna dalam masyarakat. Menurut (NakhornThap, dipertahakan keberadaanya oleh menyelesaikan masalah yang ada di

1996) kearifan lokal merupakan pengetahuan dasar yang diperoleh dari kehidupan yang seimbang dengan alam, dengan masalah budaya masyarakat yang ada dan diwarisi. kearifan lokal dapat berupa pengetahuan lokal, keterampilan lokal, intelegent lokal, sumber daya lokal, proses sosial lokal, nilai-nilai atau normanorma lokal dan adat istiadat setempat (Wagiran, 2011).

Kearifan lokal yang diintegrasikan dalam pembelajaran matematika akan memberikan nuansa baru bagi peserta didik. Belajar di sekolah, khususnya sains akan sangat menyenangkan jika disajikan dalam konteks yang menyenangkan seperti kearifan lokal daerah (Dewi, Poedjiastoeti, \& Prahani, 2017). Pembelajaran berbasis proyek (PjBL) dengan melibatkan Kearifan Lokal (KA) dapat mengembangkan berbagai keterampilan yang dibutuhkan. Keterampilan tersebut dapat diperoleh melalui pembelajaran matematika yang dipadukan dengan pengetahuan budaya lokal.

Berberapa penelitian terdahulu telah menerapkan PjBL ini dengan dikaitkan pada variable penelitian lainnya, yaitu: PjBL diterapkan pada pembelajaran Mood, Understand, Recall, Detect, Elaborate, and Review (Sumartini, 2017); PjBL pada materi statistika SMP (Maryati, 2018); dan pengembangan perangkat pembelajaran (Kurniawati \& Rizkianto, 2018).

Prinsip-prinsip PjBL-KA tidak hanya diperlukan siswa di sekolah, namun penting dimiliki oleh calon-calon pendidik 2
Mosharafa: Jumal Pendidikan Matematika Volume 9, Nomor 1, Januari 2020 Copyright $\odot 2020$ Mosharafa: Jurnal Pendidikan Matematika 
di masa mendatang sebagai calon guru khususnya di bidang pendidikan matematika bagi pengembangan potensi guna mempersiapkan diri dengan berbagai keterampilan yang dibutuhkan. Nur dan Mardjuki (2017) menyatakan bahwa mahasiswa calon guru hendaknya mempersiapkan diri dengan berbagai keterampilan intelektual yang memadai.

Keterampilan intelektual yang perlu dimiliki calon guru dapat diperoleh dengan memiliki kemampuan berpikir kreatif yang tinggi dalam memecahkan permasalahan (Tarlina \& Afriansyah, 2016). Terdapat dua komponen penting dalam berpikir kreatif yaitu keseimbangan antara logika dan intuisi (Nasution \& Surya, 2017). Logika dan intuisi tersebut dapat diperoleh melalui pembelajaran PjBL-KA. Pembelajaran PjBL-KA memberikan kesempatan kepada mahasiswa melalui proyek pembelajaran untuk dapat mengembangkan kemampuan berpikir kreatif dengan memunculkan ide/gagasan terkait kearifan lokal berdasarkan pengetahuan matematika yang dimiliki. (Rose, Colin, 2015) menyatakan kunci kreativitas adalah memperoleh secara detail pengetahuan dasar pada subjek. Artinya keterampilan mencari hubungan khusus antara budaya dan matematika dalam pembelajaran PjBLKA dapat mendorong mahasiswa berpikir kreatif berdasarkan subjek budaya dan matematika. Mahasiswa dilatih bekerja mandiri untuk dapat menghasilkan suatu produk hasil karya sendiri, sehingga kemandirian belajar mahasiswa juga akan meningkat dan lebih baik.

Berdasarkain uraian sebelumnya, maka tujuan penelitian ini adalah mengembangkan model PjBL-KA yang berorientasi pada peningkatan kemampuan berpikir kreatif matematis dan motivasi belajar mahasiswa serta mendeskripsikan kualitas model PjBL berbasis kearifan lokal ditinjau dari aspek kevalidan, kepraktisan dan keefektifan.

\section{Metode}

Penelitian ini merupakan penelitian pengembangan dengan menggunakan model penelitian yang dikembangkan oleh (Sivasailam Thiagarajan Dorothy a'., 1974) yaitu model 4D meliputi Define, Design, Development and Dissemination. Penelitian ini dilaksanakan di Universitas Majalengka Kabupaten Majalengka Jawa Barat dari bulan Februari hingga Juli 2019. Populasi penelitian yaitu mahasiswa Program Studi Pendidikan Matematika Universitas Majalengka dengan subjek uji coba terbatas melibatkan 9 mahasiswa yang memiliki kategori kemampuan tinggi, sedang dan rendah. Sedangkan subjek uji coba lapangan melibatkan 1 kelas uji coba yakni mahasiswa semester II Tahun Ajaran 2018/2019. Jumlah mahasiswa pada kelas uji coba adalah 15 mahasiswa.

Teknik analisis data yang digunakan untuk kevalidan dan kepraktisan model adalah teknik analisis data dengan menggunakan 5 kategori pilihan dengan 5 penilaian yang dirujuk pada tabel kategori 
Tabel 1.

Kategori Konversi Data Hasil Uji Validasi

\begin{tabular}{|cc|}
\hline \multicolumn{1}{c}{ Interval Skor } & Kategori \\
\hline$x>\bar{X}_{l}+1,8 S b_{i}$ & $\begin{array}{c}\text { Sangat } \\
\text { Valid/Praktis }\end{array}$ \\
\hline $\bar{X}_{l}+0,6 S b_{i}<x<\bar{X}_{l}+1,8 S b_{i}$ & Valid/Praktis \\
\hline $\bar{X}_{l}-0,6 S b_{i}<x<\bar{X}_{l}+0,6 S b_{i}$ & $\begin{array}{c}\text { Cukup } \\
\text { Valid/Praktis }\end{array}$ \\
\hline $\bar{X}_{l}-1,8 S b_{i}<x<\bar{X}_{l}-0,6 S b_{i}$ & $\begin{array}{c}\text { Kurang } \\
\text { Valid/Praktis }\end{array}$ \\
\hline$x<\bar{X}_{l}-1,8 S b_{i}$ & Tidak \\
& Valid/Praktis
\end{tabular}

konversi menurut (Azwar, 2015) seperti pada Tabel 1.

$\bar{X}_{l}$ adalah rata-rata skor ideal yaitu $1 / 2$ (skor maks + skor $\mathrm{min}$ ), $S b_{i}$ adalah simpangan baku ideal yaitu 1/6 (skor maks - skor min) dan $x$ adalah skor aktual.

Uji keefektifan model PjBL-KA menggunakan uji statistika independent sample $t$ test pada hasil tes kemampuan berpikir kreatif matematis. Kemandirian belajar dianalisis menggunakan uji regresi sederhana anova satu jalur berdasarkan hasil angket dan nilai post-test untuk mengetahui pengaruh kemandirian belajar mahasiswa terhadap kemampuan berpikir kreatif pada penggunaan model PjBL-KA.

\section{Hasil dan Pembahasan}

\section{A. Tahap Pendefinisian (Define)}

Tahap define merupakan tahap awal untuk menetapkan bagaimana syarat pengembangan model pembelajaran sesuai kebutuhan pengguna. Terdapat lima tahap analisis yaitu: (a) analisis awal akhir; (b) analisis kurikulum; (c) analisis mahasiswa; (d) analisis materi, dan (e) analisis tujuan akhir pembelajaran. Lima tahapan analisis ini dapat dilakukan dengan melakukan observasi lapangan dan di pustaka. Pada tahap ini dilakukan juga FGD sebagai langkah awal pendefinisian model pembelajaran yang akan dilakukan bersama tim ahli.

\section{B. Tahap Desain Produk (Design)}

Jahap desain produk merupakan tahap awal perancangan model pembelajaran yang akan dikembangkan yaitu: (a) pemilihan media; (b) format pembelajaran; dan (c) desain produk awal. Media penelitian yang digunakan adalah panduan proyek penelitian PJBL-KA yang disusun secara sistematis sesuai dengan budaya lokal yang akan di teliti. Format pembelajaran yang dikembangkan adalah pembelajaran berbasis proyek. Proyek dilakukan dengan mengunjungi daerah yang berpotensi memiliki kearifan lokal. Budaya yang diamati adalah budaya Majalengka diantaranya adalah kawasan terasering panyaweuyan di Kecamatan Argapura, kawasan kerajaan Talaga Manggung di kecamatan Talaga serta tarian Sampyong. Proyek dirancang peneliti untuk mencari hubungan atau keterkaitan antara budaya lokal majalengka dengan konsep matematika yang telah diketahui sebelumnya. Selanjutnya hasil proyek penelitian dapat disajikan dalam bentuk artikel, poster, makalah, dan presentasi atau pun lain sebagainya yang disebut dengan produk penelitian.

Pada desain awal produk, dihasilkan konsep dalam proses menghasilkan pengetahuan baru dari model PjBL-KA. 


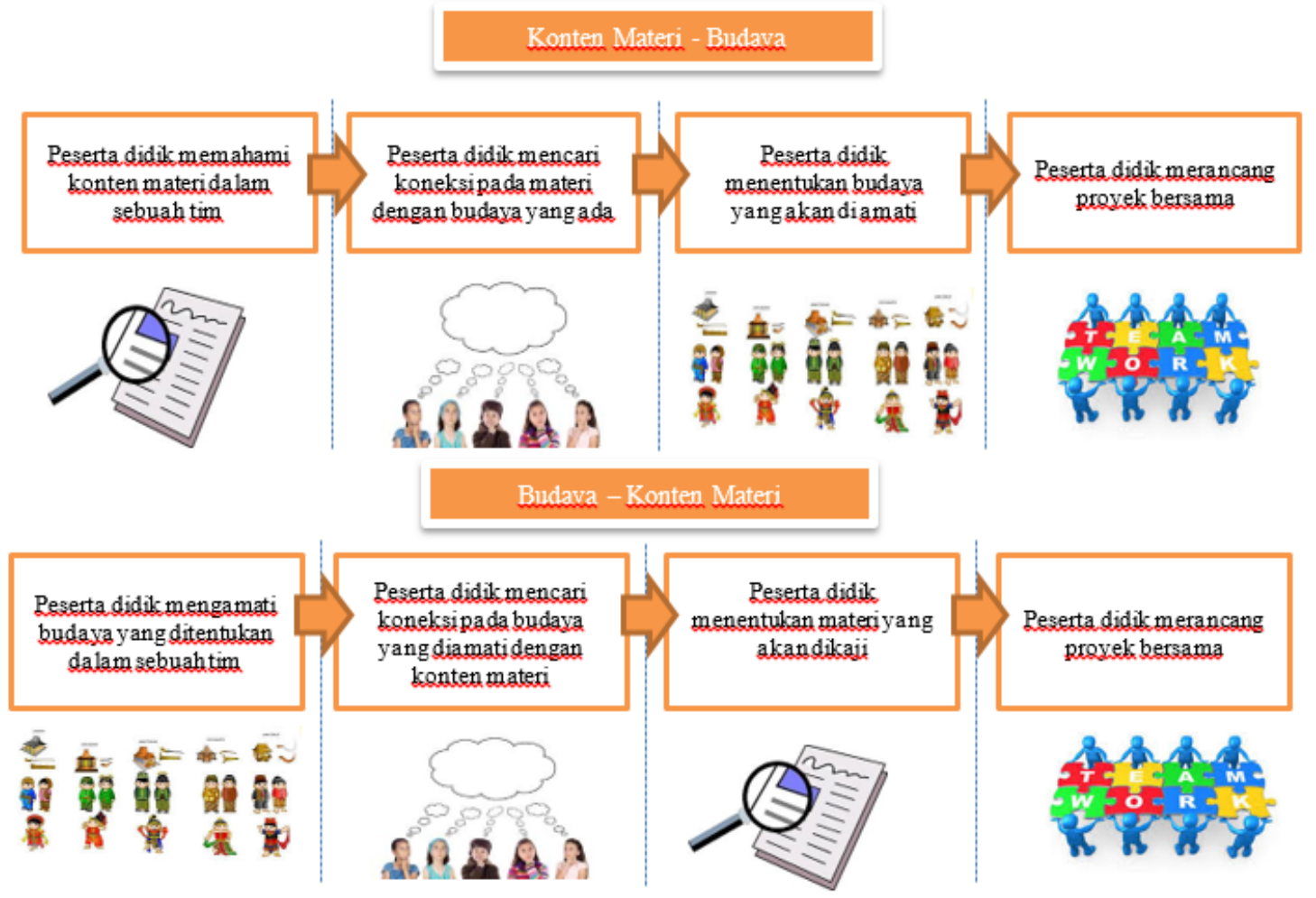

Gambar 1. Ilustrasi Proses PjBL-KA

Berdasarkan aktivitasnya, model PjBL-KA dapat dibedakan menjadi dua proses yang disajikan pada ilustrasi gambar 1.

Berdasarkan Gambar 1, terdapat dua proses dalam melakukan proses dalam pembelajaran berdasarkan model PjBL-KA. Proses pertama adalah konten materi budaya, artinya pengetahuan baru akan diperoleh dari materi yang dipelajari terlebih dahulu, selanjutnya menghubungkan konsep matematika yang dipelajari untuk menentukan budaya mana yang cocok dan memiliki keterkaitan dengan konsep matematika. Proses kedua adalah buaya - konten materi, artinya pengetahuan baru akan diperoleh dengan melihat, mengamati dan mencoba budaya lokal terlebih dahulu, selanjutnya mencari keterkaitan antara budaya yang telah diamati dengan konsep matematika yang telah diketahui.

Berdasarkan tahapan yang telah dilakukan sebelumnya, berikut adalah karakteristik pada model awal yang dikembangkan.

Karakteristik dan sintak awal pada Tabel 2 merupakan desain awal dalam mengembangkan model pembelajaran model PjBL-KA. Model PjBL-KA merupakan modifikasi model PjBL dengan konsep kearifan lokal yang dipadukan. Sintak yang didesain juga memuat identifikasi budaya yang akan dikaji.

\section{Hasil Uji Coba Produk}

1) Hasil Uji Validasi ahli

Tahap uji validasi merupakan tahap awal untuk mengetahui kelayakan model 
Tabel 2.

Karakteristik dan Sintak Model PjBL-KA

\begin{tabular}{|c|c|c|c|}
\hline $\begin{array}{c}\text { Urutan } \\
\text { Pengembangan }\end{array}$ & Keterangan & $\begin{array}{c}\text { Karakteristik } \\
\text { Model Pembelajaran PjBL- } \\
\text { KA }\end{array}$ & $\begin{array}{c}\text { Sintak } \\
\text { Model Pembelajaran PjBL-KA }\end{array}$ \\
\hline $\begin{array}{l}\text { Desain model } \\
\text { awal }\end{array}$ & $\begin{array}{l}\text { Dikembangkan } \\
\text { berdasarkan } \\
\text { model } \\
\text { pembelajaran } \\
\text { berbasis proyek } \\
\text { (Project Based } \\
\text { Learning) dan } \\
\text { integrasi nilai } \\
\text { budaya lokal } \\
\text { (Kearifan lokal) }\end{array}$ & $\begin{array}{l}\text { Pembelajaran berpusat } \\
\text { pada peserta didik } \\
\text { Menekankan pada } \\
\text { kemampuan koneksi } \\
\text { Menekankan pada } \\
\text { kemampuan berpikir kreatif } \\
\text { Menghasilkan pengetahuan } \\
\text { baru } \\
\text { Produk yang dihasilkan } \\
\text { memuat unsur budaya }\end{array}$ & $\begin{array}{l}\text { Tahap Pendahuluan } \\
\text { Tahap Identifikasi Budaya } \\
\text { Tahap Identifikasi Masalah } \\
\text { Tahap membuat desain dan jadwal } \\
\text { pelaksanaan proyek } \\
\text { Tahap pelaksanaan proyek } \\
\text { Tahap membuat produk } \\
\text { Tahap evaluasi produk } \\
\text { Tahap akhir } \\
\text { Tahap evaluasi }\end{array}$ \\
\hline
\end{tabular}

PjBL-KA oleh para ahli. Validasi model model PjBL-KA dapat dikatakan valid PjBL-KA melibatkan tiga ahli yaitu (a) dengan kategori validitas "Tinggi". validator $1 \mathrm{lbu}$ Nia Kania, M.Pd, Dosen Penilaian kevalidan model PjBL-KA per Pendidikan Matematika, (2) validator II Ibu komponen juga dilakukan untuk Devi Apriyuni Yonanda, M.Pd, ahli di mengetahui lebih detail kevalidan model bidang pengembangan model dan (3) PjBL-KA. Hasil analisis kevalidan model validator III Bapak Erik Santoso, M.Pd, PjBL-KA per komponen dapat dilihat pada Dosen pengampu mata kuliah pada subjek Tabel 4. penelitian. Hasil validasi model PjBL-KA dari masing-masing validator dapat dilihat pada Tabel 3.

Berdasarkan hasil analisis kevalidan model PjBL-KA dari tiga validator di atas dapat diketahui bahwa ketiga validator memberikan penilaian kevalidan dengan kategori "Tinggi" pada model PjBL-KA yang dikembangkan. Dapat disimpulkan bahwa

Tabel 3.

Hasil Analisis Kevalidan Model PjBL-KA

\begin{tabular}{lllll|}
\hline Validator & Skor & Interval & Kategori \\
\hline I & 37 & $34,1<x<47,3$ & Tinggi \\
\hline II & 39 & $34,1<x<47,3$ & Tinggi \\
\hline III & 37 & $34,1<x<47,3$ & Tinggi \\
\hline Total & 113 & & \\
\hline $\begin{array}{l}\text { Rata- } \\
\text { Rata }\end{array}$ & 37,67 & $34,1<x<47,3$ & Tinggi \\
\hline
\end{tabular}

6
Berdasarkan Tabel 4 diketahui bahwa rata-rata penilaian kevalidan dari ketiga validator adalah tinggi. Penilaian kevalidan

Tabel 4.

Hasil Analisis Kevalidan Model PjBL-KA Per Komponen

\begin{tabular}{|c|c|c|}
\hline $\begin{array}{c}\text { Komponen yang } \\
\text { Dinilai }\end{array}$ & Validator & Kategori \\
\hline \multirow[t]{3}{*}{ Teori Pendukung } & 1 & Tinggi \\
\hline & II & Tinggi \\
\hline & III & Sangat Tinggi \\
\hline Rata-Rata & & Sangat Tinggi \\
\hline \multirow{3}{*}{$\begin{array}{l}\text { Struktur Model PjBL- } \\
\text { KA }\end{array}$} & 1 & Sangat Tinggi \\
\hline & $\|$ & Tinggi \\
\hline & III & Sangat Tinggi \\
\hline Rata-Rata & & Sangat Tinggi \\
\hline \multirow[t]{3}{*}{ Hasil yang Diinginkan } & I & Tinggi \\
\hline & $\|$ & Tinggi \\
\hline & III & Sangat Tinggi \\
\hline Rata-Rata & & Tinggi \\
\hline
\end{tabular}

Mosharafa: Jumal Pendidikan Matematika Volume 9, Nomor 1, Januari 2020

Copyright $\odot 2020$ Mosharafa: Jurnal Pendidikan Matematika 
tersebut diberikan terhadap model PjBLKA per komponen.

Berikut adalah beberapa saran dari validator terkait perbaikan model PjBL-KA yang telah dibuat, diantaranya adalah:

Validator 1 memberikan saran perbaikan pada tatanan penulisan dan bahasa yang digunakan pada buku model yang dikembangkan.

Validator II memberikan saran agar penjelasan model dan karakteristik agar dijelaskan lebih detail sehingga terlihat komponen yang sudah dikembangkan.

Validator III memberikan saran untuk menambahkan teori kearifan lokal.

\section{2) Hasil Uji coba terbatas}

Tahap uji coba terbatas adalah tahap awal dari pelaksanaan tahap uji coba lapangan. Tahap ini dilakukan pada skala kecil dengan melibatkan 9 mahasiswa dengan kemampuan akademik berbeda yaitu 3 mahasiswa dengan kemampuan tinggi, 3 mahasiswa dengan kemampuan sedang dan 3 mahasiswa dengan kemampuan rendah serta 1 dosen pengampu mata kuliah. Berikut adalah tabel penilaian pada uji coba terbatas dari kesembilan mahasiswa disajikan pada table 5 .

Berdasarkan Tabel 5, diperoleh bahwa kepraktisan model PjBL-KA oleh dosen pengampu mendapatkan rata-rata nilai 52 pada kategori "praktis" dan rata-rata nilai sebesar 35,13 berada pada kategori "praktis" dari kesembilan mahasiswa. Secara umum penilaian kepraktisan model PjBL-KA oleh dosen dan mahasiswa adalah praktis dalam arti model PjBL-KA dapat digunakan dalam proses pembelajaran pada tahap uji coba lapangan.

3) Hasil Uji coba lapangan

Tahap uji coba lapangan terdiri dari 2 tahap yaitu tahap uji kepraktisan (secara luas) dan uji keefektifan model PjBL-KA.

a) Tahap Uji kepraktisan model PjBL$\mathrm{KA}$

Uji kepraktisan model PjBL-KA pada uji lapangan meliputi uji kepraktisan oleh dosen dan uji kepraktisan oleh mahasiswa. Dosen pengampu memberikan penilaian terhadap model PjBL-KA yang telah digunakan. Uji kepraktisan model ini juga dilakukan melalui penilaian model oleh seluruh mahasiswa pada kelas penelitian dengan jumlah 15 mahasiswa. Penilaian kepraktisan dilakukan dengan mengisi lembar penilaian yang telah disediakan.

Berikut adalah tabel hasil penilaian kepraktisan oleh dosen

Tabel 5.

Penilaian Kepraktisan Model PjBL-KA pada Tahap Uji Coba Terbatas

\begin{tabular}{|ccccc|}
\hline \multirow{1}{*}{ Penilai } & $\begin{array}{c}\text { Kategori } \\
\text { Kemampuan }\end{array}$ & $\begin{array}{c}\text { Rata-Rata Total } \\
\text { Skor }\end{array}$ & Interval & $\begin{array}{c}\text { Kategori } \\
\text { Kepraktisan }\end{array}$ \\
\hline Dosen & - & 52 & $50,4<x<61,2$ & Praktis \\
\hline Mahasiswa & Tinggi & 32 & $28<x<34$ & Praktis \\
\cline { 2 - 5 } & Sedang & 36 & $x>34$ & Sangat Praktis \\
\cline { 2 - 5 } & Rendah & 35 & $x>34$ & Sangat Praktis \\
\hline
\end{tabular}

$\bar{M}$ osharafa: Jurnal Pendidikan Matematika

Volume 9, Nomor 1, Januari 2020

Copyright @ 2020 Mosharafa: Jurnal Pendidikan Matematika 
Tabel 6 .

Hasil Penilaian Kepraktisan Model PjBL-KA

\begin{tabular}{cccc}
\hline Penilai & $\begin{array}{c}\text { Rata } \\
\text { Skor }\end{array}$ & Interval & Kategori \\
\hline Dosen & 53 & $50,4<x<61,2$ & Praktis \\
\hline $\begin{array}{c}\text { Mahasi } \\
\text { swa }\end{array}$ & 35,13 & $x>34$ & $\begin{array}{c}\text { Sangat } \\
\text { praktis }\end{array}$ \\
\hline
\end{tabular}

pengampu dan mahasiswa pada uji coba lapangan terhadap model PjBL-KA (lihat tabel 6).

Perhitungan nilai kepraktisan untuk dosen dan mahasiswa memiliki penilaian kepraktisan berbeda didasarkan pada jumlah pernyataan pada lembar kepraktisan masing-masing, sehingga kategori interval kepraktisan juga berbeda seperti pada Tabel 6 di atas.

b) Tahap uji keefektifan model PjBLKA

Tahap uji keefektifan dilakukan melalui pre-test dan post-test kemampuan berpikir kreatif pada kelas penelitian secara luas. Keefektifan model ditinjau dari tes di awal pembelajaran (pre-test) yang digunakan untuk mengetahui kemampuan awal mahasiswa sebelum menggunakan model PjBL-KA. Tes di akhir pembelajaran (post-test) yang digunakan untuk mengetahui kemampuan akhir mahasiswa setelah melakukan menggunakan model PjBL-KA.
Hasil analisis nilai pre-test dan post-test kemampuan berpikir kreatif matematis dapat menunjukkan bagaimana keefektifan model PjBL-KA yang dikembangkan. Analisis tes dilakukan menggunakan uji analisis statistik yaitu uji t untuk melihat signifikansi perbedaan kemampuan mahasiswa sebelum dan sesudah menggunakan model PjBL-KA. Sebelum melakukan uji t, dilakukan uji normalitas dan homogenitas sebagai uji prasyarat. Kedua data (pre-test dan post-test) telah diuji dan memenuhi uji prasyarat untuk selanjutnya dilakukan uji parametrik independent sampel $t$ test.

Hipotesis nol dan tandingannya adalah:

$H_{0}$ : Tidak terdapat perbedaan rata-rata pre-test dan post-test kemampuan berpikir kreatif $\left(\mu_{1}=\right.$ $\mu_{2}$ )

$H_{1}$ : Rata-rata post-test lebih baik dari pada rata-rata pre-test $\left(\mu_{2}>\mu_{1}\right)$

Taraf signifikansi $\propto=0,05$

Berikut adalah tabel hasil uji t kemampuan berpikir kreatif matematis kelas penelitian (lihat table 7). 
Tabel 7.

Uji t Data pretest dan Postest Kemampuan Berpikir Kreatif Matematis

\begin{tabular}{|c|c|c|c|c|}
\hline \multicolumn{3}{|c|}{$\begin{array}{l}\text { t-test for equality of means } \\
\text { (variances not assumed) }\end{array}$} & \multirow[t]{2}{*}{ Kesimpulan } & \multirow[t]{2}{*}{ Keterangan } \\
\hline $\mathrm{T}$ & $d f$ & $\begin{array}{l}\text { Sig }(2- \\
\text { tailed })\end{array}$ & & \\
\hline 53,013 & 14 & 0,000 & $\mathrm{H}_{0}$ ditolak & $\begin{array}{l}\text { Rata-rata } \\
\text { postest lebih } \\
\text { baik } \\
\text { daripada } \\
\text { rata-rata } \\
\text { pretest }\end{array}$ \\
\hline
\end{tabular}

Nilai signifikansi hasil uji independent sample $t$ test kemampuan berpikir kreatif matematis adalah 0,000 maka $\mathrm{H}_{0}$ ditolak. Hal ini berarti $\mathrm{H}_{1}$ diterima, artinya bahwa rata-rata post-test kemampuan berpikir kreatif matematis mahasiswa lebih baik secara signifikan daripada rata-rata pre-test kemampuan berpikir kreatif matematis. Siginifikansi perbedaan kemampuan berpikir kreatif sesudah dan sebelum penggunaan model PjBL-KA menunjukkan bahwa model pembelajaran PJBL-KA yang dikembangkan efektif digunakan pada pembelajaran matematika.

c) Analisis hasil angket kemandirian belajar

Kemandirian belajar dianalisis mengunakan uji statistik regresi sederhana untuk mengetahui pengaruh kemandirian belajar terhadap kemampuan berpikir kreatif mahasiswa. Hasil analisis korelasi diketahui koefisien korelasi antara kemandirian belajar dengan kemampuan berpikir kreatif sebesar $r_{x y}=$ 0,814 dan koefisien deteminasi sebesar $r^{2}=0,662$. Hal ini berarti kemandirian belajar dan kemampuan berpikir kreatif memiliki korelasi positif. Berikut adalah tabel hasil uji regresi ANOVA kemandirian belajar mahasiswa.

Berdasarkan Tabel 8, diperoleh bahwa signifikansi 0.000, maka HO ditolak. Artinya terdapat jumlah ragam yang berarti pada kemampuan berpikir kreatif matematis yang disebabkan persamaan linier antara kemampuan berpikir kreatif dengan kemandirian belajar. Hasil persamaan regeresi dan pengujian hipotesis kemandirian belajar dengan kemampuan berpikir kreatif matematis mahasiswa disajikan pada Tabel 9.

Tabel 8.

Hasil Uji Regresi Anova

\begin{tabular}{lllllll|}
\hline Model & $\begin{array}{l}\text { Sum of } \\
\text { Square }\end{array}$ & df & $\begin{array}{l}\text { Mean } \\
\text { Square }\end{array}$ & $F$ & Sig. \\
\hline \multirow{2}{*}{1} & Regression & 16.505 & 1 & 16.505 & 25.456 & $.000^{\mathrm{b}}$ \\
\cline { 2 - 7 } & Residual & 8.429 & 13 & .648 & & \\
\cline { 2 - 7 } & Total & 24.933 & 14 & & & \\
\end{tabular}


Tabel 9.

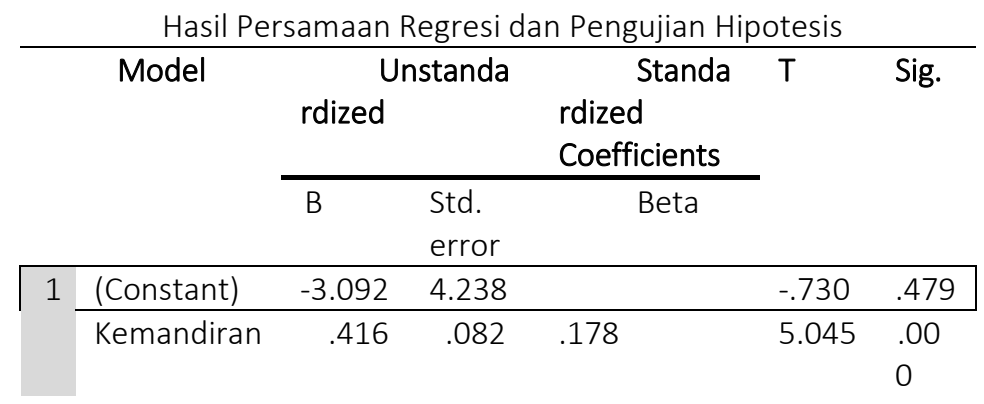

Berdasarkan Tabel 9 diperoleh bahwa persamaan regresi yang terbentuk adalah $\widehat{\mathrm{Y}}=-3.092+$ 0.416X. Nilai Sig. $=0.000<\alpha=$ 0,05, maka HO ditolak. Dapat diartikan bahwa kemandirian belajar mahasiswa berpengaruh signifikan terhadap kemampuan berpikir kreatif matematis selama menggunakan model pembelajaran PjBL-KA.

\section{Pembahasan}

Pada tahap uji coba produk menunjukkan bahwa model PjBL-KA memenuhi kriteria valid, praktis dan efektif sehingga dapat digunakan dalam pembelajaran matematika di kelas pada skala yang lebih luas. Nieveen (1999) menyatakan bahwa produk pengembangan yang berkualitas harus memenuhi kriteria kevalidan, kepraktisan dan keefektifan, diketahui bahwa model PjBL-KA di uji coba kan pada skala kecil (uji coba terbatas) dan skala besar (uji coba lapangan).

Uji validasi menunjukkan keempat validator memberikan penilaian baik terhadap model PjBL-KA dengan memberikan beberapa saran untuk perbaikan. Penilaian kepraktisan model PjBL-KA oleh dosen dan mahasiswa secara umum rata-rata adalah praktis untuk digunakan pada kelas dengan skala besar. Keefektifan model ditunjukkan berdasarkan hasil tes kemampuan berpikir kreatif

Kemampuan berpikir kreatif matematis yang dikembangkan dalam pembelajaran model PjBL-KA sangat dipengaruhi oleh kemandirian belajar mahasiswa. Artinya aspek kemandirian memiliki hubungan positif dengan model PjBL-KA yang dikembangkan. Hubungan tersebut dapat dilihat dari perilaku mahasiswa yang semangat dalam melaksanakan proyek berbasis budaya ini.

Model PjBL-KA memiliki karakteristik yang menuntut mahasiswa untuk mampu melakukan observasi, penyelidikan, pengambilan keputusan dalam setiap proses pelaksanaan proyek yang dilakukan. Dengan demikian, setiap mahasiswa memiliki rasa tanggung jawab baik secara mandiri maupun kelompok untuk melakukan tugas pembelajaran yang benar sesuai dengan kemampuan kreatifitas yang dimiliki. Seperti pendapat Yamin (2008) bahwa siswa peserta didik yang memiliki inisiatif dari dalam dirinya

\section{Mosharafa: Jumal Pendidikan Matematika} Volume 9, Nomor 1, Januari 2020 Copyright $\odot 2020$ Mosharafa: Jurnal Pendidikan Matematika 
sendiri akan bertanggung jawab secara mandiri dalam belajar mencapai tujuan.

\section{Penutup}

Penelitian ini menghasilkan sebuah model pembelajaran hasil pengembangan berdasarkan tahap uji validitas, uji kepraktisan dan uji keefektifan. Model pembelajaran yang dikembangkan telah memenuhi kriteria valid, praktis dan efektif terhadap kemampuan berpikir kreatif matematis dan kemandirian belajar mahasiswa. Dengan demikian, model PjBLKA dapat digunakan sebagai alternatif model pembelajaran baru dalam dunia pendidikan.

\section{Daftar Pustaka}

Annafi, N., \& Agustina, S. (2018). Pengembangan Model Pembelajaran Project Based Learning (PBL) Berbasis Kearifan Lokal Untuk Mempersiapkan Calon Pendidik Yang Berbudaya Development of Learning Model Project Based Learning (PBL) Based on Local Wisdom to Prepare Cultured Educator Candid. 9(1), 1-10.

Azwar, S. (2015). Fungsi Pengembangan Pengukuran Prestasi Belajar (2nd ed.). Yogyakarta: Pustaka Pelajar.

Dewi, I. N., Poedjiastoeti, S., \& Prahani, B. K. (2017). EISII Learning Model Based Local Wisdom To Improve Students' Problem Solving Skills and Scientific Communication. International Journal of Education and Research, 5(1), 107118.
Kurniawati, V., \& Rizkianto, I. (2018). Pengembangan Perangkat Pembelajaran Matematika Berbasis Guided Inquiry dan Learning Trajectory Berorientasi pada Kemampuan Pemecahan Masalah. Mosharafa: Jurnal Pendidikan Matematika, 7(3), 369-380. DOI: https://doi.org/10.31980/mosharafa.v $\underline{7 i 3.38}$

Maryati, I. (2018). Penerapan Model Pembelajaran Berbasis Proyek dalam Materi Statistika Kelas VIII Sekolah Menengah Pertama. Mosharafa: Jurnal Pendidikan Matematika, 7(3), 467-476.

DOI: https://doi.org/10.31980/mosharafa.v 7i3.26

Mungmachon, M. R. (2012). Knowledge and Local Wisdom: Community Treasure. International Journal of Humanities and Social Science, 2(13), 174-181.

Nur, F. F., \& Mardjuki, S. (2017). Peningkatan Aktivitas Belajar Matematika Siswa Melalui Penerapan Model Pembelajaran Project Based Learning ( $\mathrm{PjBL}$ ) Dengan Pemanfaatan Blog Siswa Pada Materi Nilai Mutlak dan Matrik. Jurnal Pendidikan Matematika Dan Matematika (JPMM), 1(6), 1-7. Retrieved from http://jurnal.fkip.uns.ac.id/index.php/ matematika/article/view/11376/8128 NakhornThap, S. (1996). Report of Study on Patterns of Process in Promoting Teacher and School Participation for Prevention and Solution of Problems 
Concerning Child Labor in Thailand. Journal of Research an Humanities. Information Study. Office of National Education Commission.

Rose, C, M. J. N. (2015). Resolusi Belajar: Accelerated Learning for The 21st Century. In Accelerated Learning for The 21st Century. Bandung: Nuansa Cendekia.

Sivasailam Thiagarajan Dorothy a'., ammel M. I. S. (1974). Instructional Decelopment For Training Teachers of Exception Children. A Sourcebook ERIC, (Mc), 1-193.

Suastra, I. W. (2005). Merekonstruksi Sains Asli (Indigenous Science) dalam Rangka Mengembangkan Pendidikan Sains Berbasis Budaya Lokal di Sekolah: Studi Etnosains pada Masyarakat Penglipuran Bali. Jurnal Pendidikan Dan Pengajaran IKIP Negeri Singaraja, 3(1), 377-396.

Sumartini, T. (2017). Pembelajaran Mood, Understand, Recall, Detect, Elaborate, And Review (MURDER) Berbasis Proyek Dalam Pembelajaran Matematika. Mosharafa: Jurnal Pendidikan Matematika, 6(3), 397406.

DOI:

https://doi.org/10.31980/mosharafa.v $\underline{6 i 3.328}$

Tarlina, W., \& Afriansyah, E. A. (2016). Kemampuan Berpikir Kreatif Siswa Melalui Creative Problem Solving. Eduma: Mathematics Education Learning and Teaching, 5(2), 42-51.

Nasution, T.K., Surya E., H. S. (2017). An Analysis of Student's Mathematical
Creative Thinking Ablility Senior High School on Geometry. International Journal of Advance Research and Innovative Ideas in Education., 3(2), 3860-3866.

Wagiran. (2011). Pengembangan Model Pendidikan Kearifan Lokal Dalam Mendukung Visi Pembangunan Provinsi Daerah Istimewa Yogyakarta 2020 (Tahun Kedua). Jurnal Penelitian Dan Pengembangan N, 3(5), 1-29.

Yamin, M. (2008). Desain Pembelajaran Berbasis Tingkat Satuan Pendidikan. Jakarta: Persada Pers.

\section{Riwayat Hidup PenUlis}

\section{lik Nurhikmayati, S.Si., M.Pd.}

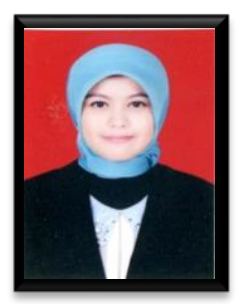

Lahir di Majalengka, 17 April 1987. Menyelesaikan pendidikan S1 pada Program Studi Matematika, Universitas Pendidikan Indonesia (UPI) Bandung dan lulus pada tahun 2009. Pendidikan S2 pada Program Studi Pendidikan Matematika PascaSarjana Universitas Pendidikan Indonesia (UPI) Bandung dan lulus pada Tahun 2012. Saat ini bekerja sebagai dosen tetap di Program Studi Pendidikan Matematika di Universitas Majelangka.

\section{Aep Sunendar, M.Pd.}

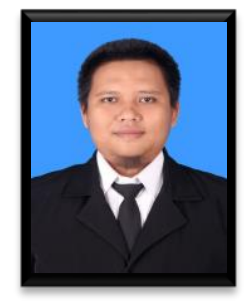

Lahir di Ciamis, 13 April 1987. Menyelesaikan pendidikan S1 pada Program Studi Pendidikan Matematika Universitas Siliwangi Tasikmalaya dan lulus pada tahun 2010. Pendidikan S2 pada Program Studi Pendidikan Matematika Program Pasca Sarjana Universitas Negeri Yogyakarta dan lulus tahun 2015 dengan beasiswa BPPDN Kemenristekdikti. 